\title{
Reorganization of Actin in Depolarized Synaptosomes ${ }^{1}$
}

\author{
B. W. BERNSTEIN AND J. R. BAMBURG ${ }^{2}$
}

Department of Biochemistry and Graduate Program in Cellular and Molecular Biology, Colorado State University, Fort Collins, Colorado 80523

\begin{abstract}
Depolarization of whole brain synaptosomes, which stimulates transmitter release, also affects regulation of the assembly of actin microfilaments. Lysates of depolarized synaptosomes contain $\mathbf{2 0} \%$ less cytoskeletal actin than lysates of unstimulated synaptosomes. Parameters affecting the assembly of actin are modified before lysis, but release of actin from the Triton-insoluble cytoskeleton does not occur until after lysis. Actin released from the cytoskeleton is not precipitated with myosin, indicating that it consists of monomers and/or short oligomers. Synaptosomes were incubated for $12 \mathrm{sec}$ in one of three solutions of identical ionic strength but of different salt mixtures: $75 \mathrm{~mm} \mathrm{KCl}-2 \mathrm{~mm} \mathrm{CaCl}_{2}, 5 \mathrm{~mm} \mathrm{KCl}-$ $2 \mathrm{~mm} \mathrm{CaCl}$, or $75 \mathrm{~mm} \mathrm{KCl-0.1} \mathrm{mM} \mathrm{EGTA.} \mathrm{Synaptosomes} \mathrm{were}$ then lysed in an F-actin stabilizing buffer containing $1 \%$ Triton $X-100$. Control synaptosomes (no incubation) were lysed directly into the same lysis buffer containing one of the three different salt mixtures. The cytoskeletal and noncytoskeletal actin pools were separated $25 \mathrm{sec}$ after lysis by centrifugation at $10^{4} \times \mathrm{g}$ for $1 \mathrm{~min}$, and the actin in each pool was quantitated by the DNase I inhibition assay. The drop in cytoskeletal actin induced by depolarization is maximized by including $\mathrm{Ca}^{2+}$ in the depolarizing buffer, and it is blocked completely by adding a neutral thiol protease inhibitor, leupeptin, to either the pre- or post-lysis buffer. The drop is also completely reversed by repolarizing the synaptosomes.
\end{abstract}

Our understanding of the molecular events in nerve terminal functioning has expanded in the last few years. One area that has come under close scrutiny is neurotransmitter secretion. Several investigators have used brain synaptosome preparations to study $\mathrm{Ca}^{2+}$ influx, transmitter release, and protein phosphorylation (DeLorenzo, 1980; Drapeau and Blaustein, 1983; Robinson and Dunkley, 1983; Suszkiw and O'Leary, 1983). A rapid influx of $\mathrm{Ca}^{2+}$ is necessary for transmitter release (Drapeau and Blaustein, 1983), and this influx is also correlated with a phosphorylation of onc group of proteins and a dephosphorylation of another (Robinson and Dunkley, 1983). Calcium entry during the first few seconds of depolarization in high external $\mathrm{K}^{+}$is the limiting step for transmitter release from rat striatal synaptosomes (Drapeau and Blaustein, 1983). Synaptosomes have three groups of $\mathrm{Ca}^{2+}$ channels: fastinactivating, slow-inactivating, and non-inactivating or nearly noninactivating. Suszkiw and O'Leary (1983) have suggested that the

Received January 30, 1984; Revised February 21, 1985;

Accepted February 22, 1985

\footnotetext{
1 This work was supported by Grant GM 35126 and a Biomedical Research Support Group grant from the National Institutes of Health.

${ }^{2}$ To whom correspondence should be addressed.
}

amount of transmitter released may depend upon the deactivation kinetics of the voltage-sensitive $\mathrm{Ca}^{2+}$ channels during maintained depolarization with high $\mathrm{K}^{+}$.

A few studies have concerned the role of microtubules in this process (O'Leary and Suszkiw, 1983), but to our knowledge none have considered the role of actin microfilaments, which are a prominent ultrastructural feature in the leading edge of the immature synaptic ending (or growth cone; Yamada et al., 1971; Bunge, 1973; Spooner and Halladay, 1981; Letourneau, 1983; Tsui et al., 1983) and in the mature synaptic ending (Drenckhahn and Kaiser, 1983). We are taking a first step in this direction by asking whether there is a change in the parameters regulating the assembly of the actin during $\mathrm{K}^{+}$depolarization and $\mathrm{Ca}^{2+}$ entry that immediately precede transmitter release. This study indicates that there is such a change.

Monomeric and filamentous actin levels have been measured in three non-neuronal secretory systems: platelet (Carlsson et al., 1979; Fox et al., 1984; Loftus et al., 1984), pancreatic $\beta$-cell (SwanstonFlatt et al., 1980), and neutrophil (White et al., 1983; Wallace et al., 1984). Each of these non-neuronal systems shows an increase in Factin upon stimulation of secretion. Synaptosomes do not. The platelet and neutrophil systems show an increase in cytoskeletal actin (White et al., 1983; Fox et al., 1984); synaptosomes show a decrease in cytoskeletal actin and an increase in monomeric actin upon stimulation of secretion.

\section{Materials and Methods}

Buffers. All pre-lysis buffers contained $20 \mathrm{~mm}$ HEPES, pH 7.4, $1 \mathrm{~mm}$ $\mathrm{MgCl}_{2}, 10 \mathrm{~mm}$ glucose. Non-depolarizing pre-lysis buffers were as follows: 5K-EGTA buffer, containing $5 \mathrm{mM} \mathrm{KCl}, 0.1 \mathrm{~mm}$ EGTA, $145 \mathrm{~mm} \mathrm{NaCl}$, and $5 \mathrm{~K}-2 \mathrm{Ca}$ buffer, containing $5 \mathrm{mM} \mathrm{KCl}, 2 \mathrm{mM} \mathrm{CaCl}, 145 \mathrm{~mm} \mathrm{NaCl}$. Depolarizing pre-lysis buffers were: 75K-EGTA buffer, containing $75 \mathrm{~mm} \mathrm{KCl}, 0.1 \mathrm{~mm}$ EGTA, $75 \mathrm{~mm} \mathrm{NaCl}$, and $75 \mathrm{~K}-2 \mathrm{Ca}$ buffer, containing $75 \mathrm{mM} \mathrm{KCl}, 2 \mathrm{mM} \mathrm{CaCl}_{2}$, $75 \mathrm{~mm} \mathrm{NaCl}$. Cell lysis buffer consisted of $1 \%$ Triton X-100, $10 \mathrm{~mm}$ Tris-HCl, $2 \mathrm{mM} \mathrm{MgCl}_{2}, 0.2 \mathrm{mM}$ dithiothreitol (DTT). Actin extraclion buffer consisted of $2 \mathrm{~mm}$ Tris- $\mathrm{HCl}, \mathrm{pH} 8.0,1 \mathrm{~mm} \mathrm{Na}-A T P, 0.2 \mathrm{~mm} \mathrm{CaCl}_{2}, 0.5 \mathrm{~mm}$ DTT.

Synaptosome preparation. Synaptosomes were purified following the method of Hajos (1975), modified to include $0.5 \mathrm{~mm}$ EGTA in the sucrose homogenizing buffer. Hajós (1975) reported that by electron microscopic criteria, $89 \%$ of the particles purified by this procedure are synaptosomes.

The pellet from the final centrifugation was resuspended on ice in 150 to $200 \mu$ l of 5 K-EGTA to give a synaptosome stock solution. In some experiments a 35- $\mu$ l aliquot of synaptosome stock solution was used directly In others the synaptosome stock solution was diluted 30 -fold or more in $5 \mathrm{~K}$ EGTA buffer with pipetting to disperse large clumps. Monitoring by light scattering at $750 \mathrm{~nm}$ was used to determine desired dilutions of synapto somes before dividing the suspension into equal volumes, centrifugating 15 sec at $10^{4} \times g$ and resuspending on ice in $70 \mu \mathrm{l}$ of 5K-EGTA.

Synaptosome integrity and efficiency of lysis. A cytoplasmic marker lactate dehydrogenase, was used to monitor the integrity of synaptosomes under the variety of conditions to which they were subjected in later experiments. Assays were performed on the supernatant of the crude synaptosome pellet, fresh synaptosomes in a variety of solutions $(0.3 \mathrm{M}$ sucrose, all four pre-lysis buffers, and cell lysis buffer), and synaptosomes which had been 
on ice for $18 \mathrm{hr}$ after purification. The absorbance change per minute at 340 $\mathrm{nm}$ was recorded after addition of $10 \mu \mathrm{l}$ of synaptosomes to a cuvette containing $3.0 \mathrm{ml}$ of $0.2 \mathrm{M}$ Tris- $\mathrm{HCl}, \mathrm{pH} 7.3,0.22 \mathrm{~mm} \mathrm{NADH}$, and $1.0 \mathrm{~mm}$ sodium pyruvate.

Neurotransmitter release. Aliquots containing $35 \mu$ l of synaptosome stock solution were added to $35 \mu$ of $\left[{ }^{3} \mathrm{H}\right]$ choline chloride $(1.0 \mu \mathrm{Ci}$ or $80 \mathrm{Ci} / \mathrm{mmol}$, New England Nuclear) in 5K-EGTA and incubated at $30^{\circ} \mathrm{C}$ for $20 \mathrm{~min}$. A control sample was kept on ice to determine the amount of $\left[{ }^{3} \mathrm{H}\right]$ choline nonspecifically associated with the synaptosomes. Synaptosomes were ccntrifuged for $15 \mathrm{scc}$ at $10^{4} \times g$, the supernatant was discarded, and the pellet was washed four times by resuspension in $100 \mu \mathrm{l}$ of 5K-EGTA followed by the same centrifugation. Immediately following the fourth washing, $70 \mu$ of prewarned $\left(30^{\circ} \mathrm{C}\right)$ pre-lysis bulfer (eilhter $75 \mathrm{~K}-2 \mathrm{Ca}$ or $5 \mathrm{~K}-2 \mathrm{Ca}$ ) were added. Synaptosomes were centrifuged at different time intervals (12 to $60 \mathrm{sec}$ ) following addition of pre-lysis buffer. Radioactivity (presumably $\left[{ }^{3} \mathrm{H}\right]$ acetylcholine) released was determined by measuring the radioactivity in the supernatant and pellet fractions. The percentage released was determined from the ratio of the radioactivity in the supernatant to the radioactivity in the supernatant plus pellet. The amount of radioactivity nonspecifically associated with the synaptosomes was subtracted from the radioactivity in the pellet.

Determination of cytoskeletal actin levels. Each $70-\mu$ laliquot of synaptosomes in 5K-EGTA was transferred from ice to a $30^{\circ} \mathrm{C}$ water bath, incubated for $20 \mathrm{~min}$, and centrifuged for $15 \mathrm{sec}$ at $10^{4} \times \mathrm{g}$. The supernatant was discarded, and $70 \mu \mathrm{l}$ of pre-lysis buffer were added to the pellet which was resuspended by gentle pipetting for pre-lysis incubation. Cell lysis buffer $(315 \mu l)$ was added $12 \mathrm{sec}$ later (the shortest time possible), and the mixture was pipetted for $5 \mathrm{sec}$. When synaptosomes were not incubated before lysis, $70 \mu$ l of pre-lysis buffer were mixed with $315 \mu$ of cell lysis buffer before addition to the synaptosomes. The lysate was always centrifuged for $1 \mathrm{~min}$ at $10^{4} \times \mathrm{g}$, starting $25 \mathrm{sec}$ after addition of lysis buffer. These centrifugation conditions are sufficient only to pellet that actin which is associated with cytoskeletal elements (Heacock and Bamburg, 1983) and henceforth, will be termed cytoskeletal actin. The pellet was resuspended in $200 \mu \mathrm{l}$ of actin extraction buffer. Actin in the supernatant and pellet fractions is stable for $72 \mathrm{hr}$ and was quantitated within $30 \mathrm{hr}$ by the DNase I inhibition assay as described by Heacock and Bamburg (1983). A control assay with no actin was performed for every two assays containing actin. The percentage of cytoskeletal actin is obtained from the ratio of actin in the pellet to total actin. In an experiment in which centrifugation after lysis was delayed, cytoskeletal actin of nondepolarized synaptosomes decreased at a rate of $1.5 \% / \mathrm{min}$.

Scintillation counting. Radioactivity was quantitated in a Beckman LS 7800 spectrometer following addition of $0.3 \mathrm{ml}$ of Protosol (New England Nuclear) and $4.0 \mathrm{ml}$ of toluene-based scintillation cocktail containing $0.01 \%$ 1,4-bis[2-(5-phenyloxazoyl)]benzene and 0.5\% 2,5-diphenyloxazole (Fisher Scientific Co.). With automatic quench correction, counting efficiency for ${ }^{3} \mathrm{H}$ was $48 \%$

\section{Results}

The absence of lactate dehydrogenase activity in synaptosome preparations suspended in any of the prelysis buffers or $0.3 \mathrm{M}$ sucrose indicates that synaptosomes remain intact even after storage on ice in these solutions for $18 \mathrm{hr}$. Treatment of the synaptosomes with lysis buffer under conditions used in subsequent experiments results in maximal release of lactate dehydrogenase activity.

Because our goal is to investigate the role of actin in neurotransmitter release, we chose a procedure for monitoring transmitter uptake and release which is compatible with our procedure for determining cytoskeletal actin levels. Our synaptosome preparations are capable of $\left[{ }^{3} \mathrm{H}\right]$ choline uptake; an order of magnitude more $\left[{ }^{3} \mathrm{H}\right]$ choline is taken up by synaptosomes incubated at $30^{\circ} \mathrm{C}$ than at $4^{\circ} \mathrm{C}$. Maximum release of the radioactivity (presumably as acetylcholine; Marchbanks, 1969) is dependent upon $\mathrm{K}^{+}$depolarization in the presence of $\mathrm{Ca}^{2+}$ (Fig. 1). Our procedure involved incubating the synaptosomes for the entire 12 to $60 \mathrm{sec}$ duration in stimulating buffer, centrifuging for $15 \mathrm{sec}$ at $10^{4} \times \mathrm{g}$, and removing the supernatant. Hence, it differed significantly from recent studies (Drapeau and Blaustein, 1983; Suszkiw and O'Leary, 1983) in which synaptosomes were retained on filters and perfused with stimulating buffers, and the filtrates were collected every $10 \mathrm{sec}$ for several minutes. However, both our procedure and the filter procedure result in approximately twice as much transmitter released with depolarization as without depolarization, and the percentages of total transmitter released are comparable.

Neurotransmitter release does not depend on synaptosome concentration in the stimulating buffer; however, our results indicate that careful control of synaptosome concentration is essential in experiments measuring cytoskeletal actin. Light scattering was used to monitor the dilution of the synaptosome stock solution, providing a quick and convenient technique for controlling the total actin levels used in each experiment (Fig. 2).

Figure 3 illustrates the effect of pre-lysis incubation on cytoskeletal actin. Without pre-lysis incubation the percentage of actin associated with the cytoskeleton (about $70 \%$ of the total actin) is not a function of synaptosome (or total actin) concentration; all three pre-lysis buffers result in similar cytoskeletal actin percentages at all synaptosome concentrations tested. However, when synaptosomes were depolarized in $75 \mathrm{~K}-2 \mathrm{Ca}$ buffer for $12 \mathrm{sec}$ before lysis and the synaptosome concentration was low, the cytoskeletal actin percentage drops to about $50 \%$ of total actin. Pre-lysis incubation of synaptosomes in a nondepolarizing buffer $(5 \mathrm{~K}-2 \mathrm{Ca})$ does not affect the percentage of cytoskeletal actin even at low synaptosome concentrations. Pre-lysis incubation in depolarizing buffer without $\mathrm{Ca}^{2+}$ (75K-EGTA) causes a reduction in cytoskeletal actin to an intermediate value of about $63 \%$ of total actin: a decrease which correlates with a reduction in transmitter release under $\mathrm{Ca}^{2+}$-free depolarizing conditions (Drapeau and Blaustein, 1983). Thus, we conclude the following: (1) that a decrease in the percentage of
Figure 1. Radioactivity released from synaptosomes incubated in $5 \mathrm{~K}-2 \mathrm{Ca}$ and $75 \mathrm{~K}-2 \mathrm{Ca}$. Synaptosomes were incubated in $\left[{ }^{3} \mathrm{H}\right]$ choline in 5K-EGTA for $20 \mathrm{~min}\left(30^{\circ} \mathrm{C}\right)$ and washed four times with $5 \mathrm{~K}$-EGTA $\left(4^{\circ} \mathrm{C}\right)$. Each sample was then incubated at $30^{\circ} \mathrm{C}$ in one of two pre-lysis buffers for the times indicated before being centrifuged. The percentage of radioactivity released was determined as described under "Materials and Methods." Error bars represent standard deviation of four values.

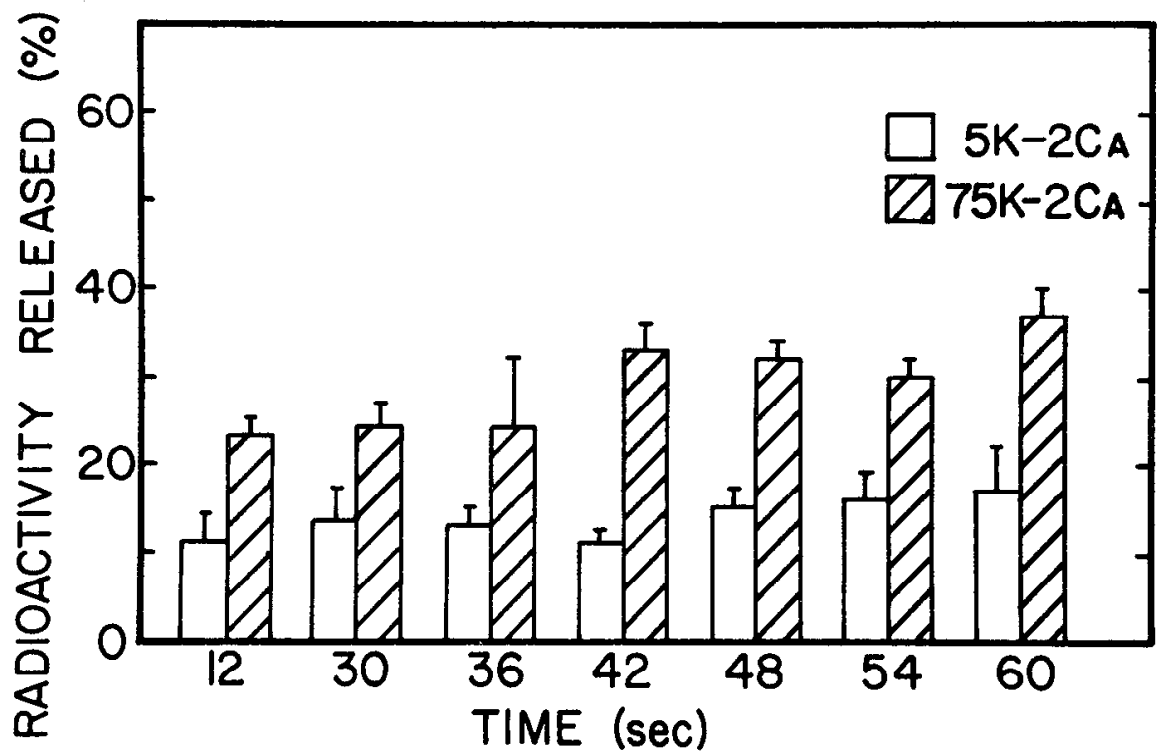




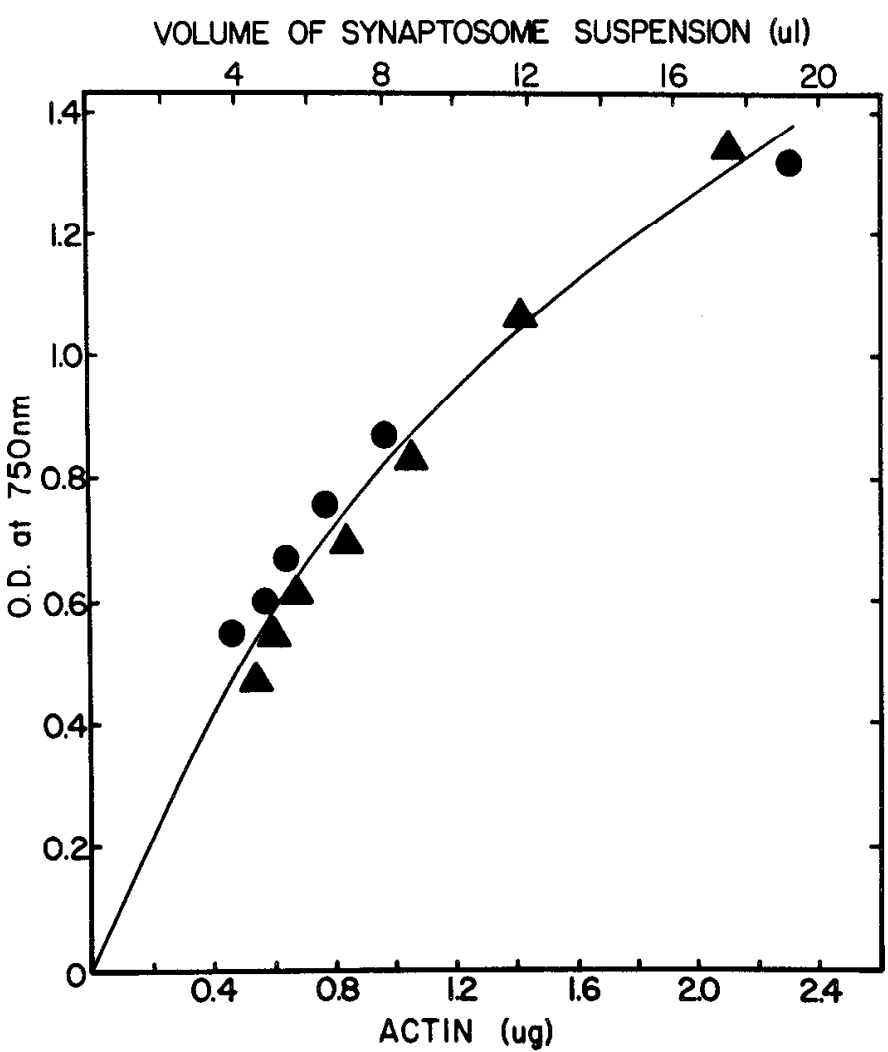

Figure 2. The relationship of total actin level to synaptosome dilution measured by light scattering. Seven different volumes of synaptosome stock suspension were diluted into $1 \mathrm{ml}$ of $5 \mathrm{~K}$-EGTA. $\mathbf{\Delta}$, mean of the light scattering reading on three samples of each dilution; - mean of the actin content of three samples at each dilution.

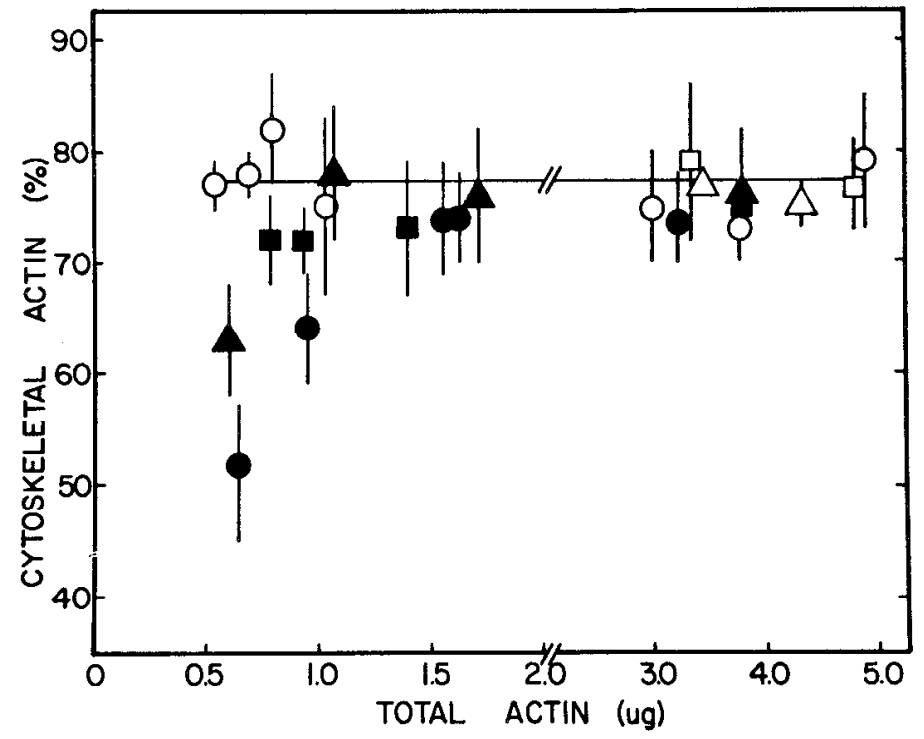

Figure 3. Effect on cytoskeletal actin levels of pre-lysis incubation in three buffers. Each sample was exposed to an equal volume $(70 \mu l)$ of one of three pre-lysis buffers either for $12 \mathrm{sec}$ before lysis (solid symbols) or at the time of lysis (i.e., $70 \mu$ included in the lysis buffer; open symbols). The same volume of lysis buffer $(315 \mu l)$ was used for all samples. The percentage of total actin which is cytoskeletal represents in most cases the mean $( \pm S D)$ of four samples with a minimum of three DNase I inhibition assays per sample. Total actin is a measure of synaptosome concentrations (Fig. 2). Final lysis buffer conditions for $75 \mathrm{~K}-2 \mathrm{Ca}$ samples are identical to those of samples 4 to 6 in Table I. The data were compiled from six experiments. Symbols represent the following pre-lysis buffers: circles, $75 \mathrm{~K}-2 \mathrm{Ca}$; triangles, $75 \mathrm{~K}-\mathrm{EGTA}$; squares, $5 \mathrm{~K}-2 \mathrm{Ca}$. actin associated with the cytoskeleton occurs only when synaptosomes are exposed to depolarizing buffers before lysis; (2) that a nondepolarizing buffer cannot bring about this change; and (3) that the presence of $\mathrm{Ca}^{2+}$ in the depolarizing buffer is necessary to maximize the decrease in the percentage of cytoskeletal actin.

However, the argument could be made that the $5 \mathrm{~K}-2 \mathrm{Ca}$ buffer might have the same effect before lysis as the $75 \mathrm{~K}-2 \mathrm{Ca}$ buffer, but because the synaptosomes after lysis are in different final buffers, the decrcasc in cytoskeletal actin does not occur. In order to address this problem, we did the following experiments: (a) incubated 12 sec in $75 \mathrm{~K}-2 \mathrm{Ca}$ and added cell lysis buffer containing $5 \mathrm{~K}-2 \mathrm{Ca}$, and (b) incubated $12 \mathrm{sec}$ in $5 \mathrm{~K}-2 \mathrm{Ca}$ and added cell lysis buffer containing $75 \mathrm{~K}-2 \mathrm{Ca}$. The cytoskeletal actin level is reduced only in experiment a (from $73 \%$ to $61 \%$ ), even though the conditions after lysis were identical. Thus, we conclude that depolarization induces before lysis an effect which is manifested after lysis by release of actin from the cytoskeleton.

The decrease in cytoskeletal actin induced by depolarization is observed only in relatively dilute synaptosome solutions (Fig. 3). In order to determine whether it is synaptosome concentration in the pre-lysis buffer or the post-lysis dilution which is responsible for the decrease in cytoskeletal actin at low synaptosome concentration, we did the following experiment. Synaptosomes were incubated before lysis at nearly identical concentrations in $75 \mathrm{~K}-2 \mathrm{Ca}$ and then diluted to different concentrations in lysis buffer with the same final ionic (or buffer) conditions (Table I, samples 4 to 6). Only those samples (Table I, samples 5 and 6) containing lower concentrations of synaptosomes in the cell lysis buffer show reduced levels of cytoskeletal actin. When synaptosomes at different concentrations were incubated in pre-lysis buffer and then lysed into a buffer which resulted in the same final protein concentration but higher levels of $75 \mathrm{~K}-2 \mathrm{Ca}$ components, all of the samples showed a decreased level of cytoskeletal actin (Table I, samples 1 to 3). Since the only difference between samples 1 and 4 was the final concentration of 75K-2Ca components (i.e., higher $\mathrm{K}^{+}$and $\mathrm{Ca}^{2+}$ in sample 1), we conclude that the post-lysis conditions influence whether or not a decrease in cytoskeletal actin will be observed following lysis of depolarized synaptosomes. In contrast, synaptosome concentration in the pre-lysis buffer is not critical.

To determine whether actin released from the cytoskeleton is monomeric or filamentous, we added rabbit muscle myosin to the post-lysis buffer (Table II). Previous studies (Heacock and Bamburg, 1983) have shown that, under these conditions of cell lysis, myosin is effective in sedimenting F-actin but has no effect on G-actin. The

TABLE

Effects of pre-and post-lysis dilution on cytoskeletal actin levels in synaptosomes

All samples were prepared and handled identically to those in Figure 3. However, all of these samples were exposed to only one pre-lysis buffer ( $75 \mathrm{~K}-2 \mathrm{Ca})$, and all were incubated for $12 \mathrm{sec}$ before the addition of lysis buffer. The cytoskeletal actin percentage $( \pm S D)$ represents the mean of four samples. A minimum of three DNase I inhibition assays was performed per sample. The values for $\mathrm{K}^{+}$and $\mathrm{Ca}^{2+}$ concentrations do not include contributions from the synaptosomes.

\begin{tabular}{|c|c|c|c|c|c|c|}
\hline \multirow[t]{2}{*}{$\begin{array}{c}\text { Sample } \\
\text { No. }\end{array}$} & \multirow{2}{*}{$\begin{array}{l}\text { Total } \\
\text { Actin } \\
(\mu \mathrm{g})\end{array}$} & \multirow{2}{*}{$\begin{array}{l}\text { Cytoskeletal } \\
\text { Actin } \\
(\%)^{2}\end{array}$} & \multicolumn{2}{|c|}{$\begin{array}{c}\text { Actin } \\
\text { Concentration } \\
(\mu \mathrm{g} / \mathrm{ml} \text { of buffer })\end{array}$} & \multicolumn{2}{|c|}{$\begin{array}{c}\text { Final Lysis } \\
\text { Buffer } \\
\text { (mM) }\end{array}$} \\
\hline & & & Pre-lysis & Post-Iysis & $\overline{k^{+}}$ & $\mathrm{Ca}^{2+}$ \\
\hline 1 & $1.87 \pm 0.31$ & $56 \pm 4$ & 27.0 & 4.9 & 42 & 1.08 \\
\hline 2 & $1.78 \pm 0.35$ & $52 \pm 4$ & 13.0 & 4.6 & 42 & 1.08 \\
\hline 3 & $1.64 \pm 0.19$ & $53 \pm 4$ & 7.8 & 4.3 & 42 & 1.08 \\
\hline 4 & $1.56 \perp 0.18$ & $74 \pm 5$ & 22.1 & 4.0 & 14 & 0.36 \\
\hline 5 & $1.60 \pm 0.40$ & $44 \pm 4$ & 22.9 & 2.1 & 14 & 0.36 \\
\hline 6 & $1.24 \pm 0.21$ & $52 \pm 3$ & 17.7 & 1.1 & 14 & 0.36 \\
\hline
\end{tabular}

${ }^{a}$ Approximately $70 \%$ of the total actin in resting synaptosomes is cytoskeletal. 
TABLE ॥

Characteristics of the decrease in cytoskeletal actin induced by depolarization

All samples were prepared and handled as in Figure 3. All final lysis buffers contained $315 \mu \mathrm{l}$ of cell lysis buffer plus $70 \mu \mathrm{l}$ of $75 \mathrm{~K}-2 \mathrm{Ca}$ buffer. Leupeptin was dissolved in $10 \%$ glycerol. Myosin (in $20 \mathrm{~mm}$ potassium phosphate buffer, $\mathrm{pH} 7.0,0.5 \mathrm{M} \mathrm{KCl}$ ) was added at a molar ratio of myosin to synaptosome actin of approximately 1 . The percentage of cytoskeletal actin represents the mean $( \pm S D$ ) of two to four experiments with four samples for each treatment; a minimum of three DNase assays was performed for each sample.

\begin{tabular}{|c|c|c|}
\hline Pre-lysis Conditions & Post-Jysis Conditions & $\begin{array}{l}\text { Cytoskeletal } \\
\text { Actin }(\%)\end{array}$ \\
\hline a. Resting: $0 \mathrm{sec}, 75 \mathrm{~K}-2 \mathrm{Ca}$ & & $69 \pm 4$ \\
\hline b. Resting: 5K-EGTA & Final lysis buffer condi- & $66 \pm 3$ \\
\hline $\begin{array}{l}\text { c. Depolarized: } 12 \mathrm{sec}, 75 \mathrm{~K}- \\
2 \mathrm{Ca}\end{array}$ & $\begin{array}{l}\text { tions were the same for } \\
\text { all samples ("standard") }\end{array}$ & $43 \pm 3$ \\
\hline $\begin{array}{c}\text { d. Resting: } 12 \mathrm{sec}, 5 \mathrm{~K}-\mathrm{EGTA} \\
\text { and } 60 \mathrm{sec}, 5 \mathrm{~K}-\mathrm{EGTA}\end{array}$ & & $64 \pm 3$ \\
\hline $\begin{array}{l}\text { e. Depolarized and repolar- } \\
\text { ized: } 12 \mathrm{sec}, 75 \mathrm{~K}-2 \mathrm{Ca} \\
\text { and } 60 \mathrm{sec}, 5 \mathrm{~K}-\mathrm{EGTA}\end{array}$ & & $71 \pm 3$ \\
\hline \multicolumn{3}{|l|}{ Myosin in post-lysis buffer } \\
\hline a. Resting: $0 \mathrm{sec}, 75 \mathrm{~K}-2 \mathrm{Ca}$ & Standard \pm myosin buffer & $62 \pm 3$ \\
\hline b. Depolarized: $75 \mathrm{~K}-2 \mathrm{Ca}$ & Standard + myosin buffer & $46 \pm 3$ \\
\hline c. Resting: $0 \mathrm{sec}, 75 \mathrm{~K}-2 \mathrm{Ca}$ & Standard + myosin & $76 \pm 1$ \\
\hline $\begin{array}{l}\text { d. Depolarized: } 12 \mathrm{sec}, 75 \mathrm{~K}- \\
\quad 2 \mathrm{Ca}\end{array}$ & Standard + myosin & $58 \pm 4$ \\
\hline \multicolumn{3}{|l|}{ Leupeptin } \\
\hline $\begin{array}{l}\text { a. Resting: } 0 \mathrm{sec}, 75 \mathrm{~K}-2 \mathrm{Ca} \\
+ \text { leupeptin buffer }\end{array}$ & & $62 \pm 3$ \\
\hline $\begin{array}{c}\text { b. Depolarized: } 12 \mathrm{sec}, 75 \mathrm{~K}- \\
2 \mathrm{Ca}+\text { leupeptin buffer }\end{array}$ & $\begin{array}{l}\text { Standard + leupeptin } \\
\text { buffer }\end{array}$ & $41 \pm 3$ \\
\hline $\begin{array}{l}\text { c. Depolarized: } 90 \mathrm{sec}, 75 \mathrm{~K}- \\
2 \mathrm{Ca}+\text { leupeptin buffer }\end{array}$ & & $43 \pm 3$ \\
\hline d. $50 \mu \mathrm{m}$ leupeptin in a. & & $59 \pm 3$ \\
\hline $\begin{array}{l}\text { e. } 50 \mu \mathrm{M} \text { leupeptin in b. } \\
\text { f. } 50 \mu \mathrm{M} \text { leupeptin in } \mathrm{C} .\end{array}$ & $\begin{array}{l}\text { Standard + leupeptin } \\
\text { buffer }\end{array}$ & $\begin{array}{l}58 \pm 3 \\
63 \pm 3\end{array}$ \\
\hline g. a. + leupeptin buffer & & $55 \pm 3$ \\
\hline h. b. + leupeptin buffer & Standard containing & $54 \pm 4$ \\
\hline i. c. + leupeptin buffer & $100 \mu \mathrm{M}$ leupeptin & $60 \pm 3$ \\
\hline
\end{tabular}

presence of myosin does not affect the decrease in cytoskeletal actin observed for depolarized synaptosomes; thus, we conclude that actin is released from the cytoskeleton as monomers or short oligomers. In addition, the decrease in cytoskeletal actin induced by depolarization can be completely reversed by incubating synaptosomes under repolarizing conditions (Table II). This is what one would expect if the depolarization approximates a normal physiolog. ical process.

The fact that leupeptin can be added after lysis and can block the decrease in cytoskeletal actin (Table II) suggests that the decrease occurs after lysis. Assuming that the only effect of leupeptin is proteasc inhibition, proteolysis is required for the release of actin. The blockage of actin release in depolarized synaptosomes incubated with leupeptin before lysis can be interpreted in several ways. It is possible that the proteolysis necessary for actin release occurs only after lysis. If this were true, the effectiveness of leupeptin in blocking actin release when present during pre-lysis incubation could be explained by the leupeptin-protease complex (formed during prelysis incubation) being sufficiently stable to retard proteolysis during lysis and centrifugation. Alternatively, the apparently required proteolysis may occur in two stages, a pre- and post-lysis stage, both of which are needed for actin to bc released in depolarized synaptosomes.
That the actual decrease in cytoskeletal actin occurs after lysis is supported by the leupeptin data (Table II) and by data in Table I. The only alternative explanation for the differences observed between samples 1 and 4 in Table $I$ is that the cytoskeletal actin decreases before lysis and recovery of cytoskeletal actin occurs after lysis only in sample 4. Recovery of cytoskeletal actin at such low concentrations is highly unlikely (Pollard and Mooseker, 1981), especially in the short time period between lysis and separation of the actin pools. An identical argument could be made with samples 4 and 5 and samples 4 and 6 of Table 1 .

\section{Discussion}

The experiments described herein demonstrate that parameters involved in regulating the assembly of actin microfilaments are modified during depolarization which releases neurotransmitter. The release of transmitter is thought to involve a fusion of synaptic vesicles with the plasma membrane (Reichardt and Kelly, 1983). We do not know whether the changes in actin regulation are essential for vesicle movement or are merely part of many events triggered by depolarization and $\mathrm{Ca}^{2+}$ influx and indirectly or not at all related to secretion. We know that, after lysis, actin must be dissociating from other cytoskeletal elements, and we know from our precipitation experiments with myosin that the actin released is in a monomeric or short oligomeric form (Heacock and Bamburg, 1983). Thus, synaptosomes differ from several non-neuronal secretory systems in which an increase in total F-actin accompanying secretion is observed after lysis (Carlsson et al., 1979; Swanston-Flatt et al., 1980; Fox et al., 1984; Wallace et al., 1984).

Two probable effects of synaptosomal depolarization with $75 \mathrm{~K}$ $2 \mathrm{Ca}$ are: (1) reorganization of the actin microfilaments which renders the actin more susceptible to dissociation from other cytoskeletal elements after lysis, and (2) activation of an actin-depolymerizing factor. If a depolymerizing factor is involved, its activation requires synaptosomal integrity, but its depolymerizing effect can only be exerted on filaments after lysis. Actin-depolymerizing factors have been isolated from brain (Bamburg et al., 1980; Petrucci and Bray, 1983; Maekawa et al., 1984) and characterized (Bernstein and Bamburg, 1982; Harris et al., 1982; Nishida et al., 1984).

Calcium influx could promote reorganization of actin microfilaments through several possible mechanisms. Calcium-sensitive cross-linking or fragmenting proteins have been identified in neural tissue. One such fragmenting protein, gelsolin, has been isolated from brain (Petrucci and Bray, 1983). An actin cross-linking protein with micromolar $\mathrm{Ca}^{2+}$ sensitivity, $\alpha$-actinin, has been isolated from brain and characterized (Duhaiman and Bamburg, 1984). If the $\mathrm{Ca}^{2+}$ flux into synaptosomes causes a gel-to-sol transformation, it could leave other actin-binding proteins, such as fodrin (Levine and Willard, 1981; Sobue et al., 1983), more vulnerable to proteolysis after lysis. A Ca ${ }^{2+}$-activated proteolytic enzyme (calpain I), which specifically degrades brain spectrin (fodrin), has been isolated from synaptosomal membranes (Baudry et al., 1981; Siman et al., 1983).

Preferential degradation of two high molecular weight proteins $\left(M_{r}\right.$ $=250,000$ and 280,000 ), similar in size to the spectrin subunits, has been reported in platelet extracts (Phillips and Jakabova, 1977). A decrease in sedimentable actin was found in lysates containing between 0.01 and $1.0 \mathrm{mM} \mathrm{Ca}^{2+}$ (Wang and Bryan, 1981). This finding parallels our results in which synaplosomes depolarized under identical conditions in $75 \mathrm{~K}-2 \mathrm{Ca}$ buffer show a reduction in cytoskeletal actin if lysed in $1.08 \mathrm{mM} \mathrm{Ca}^{2+}$ (Table I, sample 1) but not if lysed in $0.36 \mathrm{mM} \mathrm{Ca}^{2+}$ (Table I, sample 4). However, lysis in $0.36 \mathrm{mM} \mathrm{Ca}^{2+}$ can cause a decrease in cytoskeletal actin if the protein concentration is sufficiently low (Table I, samples 5 and 6). Thus, the changes which occur in depolarized synaptosomes may result in an alteration of the binding properties of actin to the cytoskeleton, such that higher $\mathrm{Ca}^{2+}$ and/or $\mathrm{K}^{+}$or lower protein concentration result in actin dissociation.

Fried and Blaustein (1978) have shown by electron microscopy that only about $40 \%$ of isolated synaptosomes undergo membrane 
recycling in response to depolarization. This suggests that the reduction in cytoskeletal actin which we observe (15 to $25 \%$ ) is a minimum of that which might be seen if one could observe exclusively responsive endings. However, since we do not know that there is a functional relationship between the depolarization effects on actin and secretion, it is possible that all synaptosomes, or even only nonfunctional synaptosomes, undergo the actin reorganization. In contrast, if it is only the functional synaptosomes in this highly heterogeneous mixture that undergo the change, then the modifications which occur before lysis would be even more extensive than this study implies.

Electrophysiological plasticity studies have shown that elevated presynaptic $\mathrm{Ca}^{2+}$ may be a key factor in increasing excitability of entrained neurons (Alkon, 1979; Kandel and Schwartz, 1982). The change in actin organization which we are reporting may facilitate vesicle movement and may in this way play an important part in the effects of elevated $\mathrm{Ca}^{2+}$ leading to increased excitability. If such a change in actin facilitates vesicle movement in the mature nerve ending, it may also facilitate fusion of phospholipid vesicles with plasma membrane in the growth cone. An enrichment of voltagesensitive $\mathrm{Ca}^{2+}$ channels was reported in the neuroblastoma growth cone (Anglister et al., 1982). These investigators, using elevated $\mathrm{K}^{\prime}$ for depolarization, have demonstrated $\mathrm{Ca}^{2+}$-dependent growth and have suggested that $\mathrm{Ca}^{2+}$ may trigger neurite elongation.

\section{References}

Alkon, D. L. (1979) Voltage-dependent calcium and potassium ion conductances: A contingency mechanism for an associative learning model. Science 205: 810-816

Anglister, L., I. C. Farber, A. Sahar, and A. Grinvald (1982) Localization of voltage-sensitive calcium channels along developing neurites: Their possible role in regulating neurite elongation. Dev. Biol. 94: 351-365.

Bamburg, J. R., H. E. Harris, and A. G. Weeds (1980) Partial purification and characterization of an actin depolymerizing factor from brain. FEBS Lett. 121: 178-182.

Baudry, M., M. Bundman, E. Smith, and G. Lynch (1981) Micromolar calcium stimulates proteolytic activity and glutamate receptor binding in rat synaptic membranes. Science 212: 937-938.

Bernstein, B. W., and J. R. Bamburg (1982) Tropomyosin binding protects the F-actin from disassembly by brain actin-depolymerizing factor (ADF). Cell Motil. 2: 1-8.

Bunge, M. B. (1973) Fine structure of nerve fibers and growth cones of isolated sympathetic neurons in culture. J. Cell Biol. 56: 713-735.

Carlsson, L., F. Markey, I. Blikstad, T. Persson, and U. Lindberg (1979) Reorganization of actin in platelets stimulated by thrombin as measured by the DNase I inhibition assay. Proc. Natl. Acad. Sci. U. S. A. 76: 63766380 .

DeLorenzo. R. J. (1980) Role of calmodulin in neurotransmitter release and synaptic function. Ann. N. Y. Acad. Sci. 356: 92-109.

Drapeau, P., and M. P. Blaustein (1983) Initial release of $\left[{ }^{3} \mathrm{H}\right]$ dopamine from rat striatal synaptosomes: Correlation with calcium entry. J. Neurosci. 3: 703-713.

Drenckhahn, D., and H. -W. Kaiser (1983) Evidence for the concentration of $\mathrm{F}$-actin and myosin in synapses and in the plasmalemmal zone of axons. Eur. J. Cell Biol. 31: 235-240.

Duhaiman, A. S., and J. R. Bamburg (1984) Isolation of brain $\alpha$-actinin. Its characterization and a comparison of its properties to muscle $\alpha$-actinins. Biochemistry 23: 1600-1608.

Fox, J. E. B., J. K. Boyles, C. C. Reynolds, and D. R. Phillips (1984) Actin filament content and organization in unstimulated platelets. J. Cell Biol. 98: 1985-1991.

Fried, R. C., and M. P. Blaustein (1978) Retrieval and recycling of synaptic vesicle membrane in pinched-off nerve terminals (synaptosomes). J. Cell Biol. 78: 685-700.

Hajós, F. (1975) An improved method for the preparation of synaptosomal fractions in high purity. Brain Res. 93: 485-489.
Harris, H. E., J. R. Bamburg, B. W. Bernstein, and A. G. Weeds (1982) The depolymerization of actin by specific proteins from plasma and brain. $A$ quantitative assay. Anal. Biochem. 119: 102-104.

Heacock, C. S., and J. R. Bamburg (1983) The quantitation of G-and F-actin in cultured cells. Anal. Biochem. 135: 22-36.

Kandel, E. R., and J. H. Schwartz (1982) Molecular biology of learning: Modulation of transmitter release. Science 218: 433-443.

Letourneau, P. C. (1983) Differences in the organization of actin in the growth cone compared with neurites of cultured neurons from chick embryos. $J$ Cell Biol. 97: 963-973.

Levine, J., and M. Willard (1981) Fodrin: Axonally transported polypeptides associated with the internal periphery of many cells. J. Cell Biol. 90: 631643.

Loftus, J. C., J. Choate, and R. M. Albrecht (1984) Platelet activation and cytoskeletal reorganization: High voltage electron microscopic examination of intact and Triton-extracted whole mounts. J. Cell Biol. 98: 2019-2025.

Maekawa, S., E. Nishida, Y. Ohta, and H. Sakai (1984) Isolation of low molecular weight actin-binding proteins from porcine brain. J. Biochem. 95: 377-385.

Marchbanks, R. M. (1969) The conversion of $\left[{ }^{14} \mathrm{C}\right]$ choline into $\left[{ }^{14} \mathrm{C}\right]$ acetylcholine in synaptosomes in vitro. Biochem. Pharmacol. 18: 1763-1766.

Nishida, E., S. Maekawa, E. Muneyuki, and H. Sakai (1984) Action of a 19K protein from porcine brain on actin polymerization: A new functional class of actin-binding proteins. J. Biochem. 95: 387-398.

O'Leary, M. E., and J. B. Suszkiw (1983) Effect of colchicine on ${ }^{45} \mathrm{Ca}$ and choline uptake, and acetycholine release in rat brain synaptosomes. $\mathrm{J}$. Neurochem. 40: 1192-1195.

Petrucci, T. C., and D. Bray (1983) Isolation of a Ca ${ }^{2+}$ dependent actinfragmenting protein from brain, spinal cord, and cultured neurones. J. Neurochem. 40: 1507-1516.

Phillips, D. R., and M. Jakabova (1977) $\mathrm{Ca}^{2+}$-dependent protease in human platelets. J. Biol. Chem. 252: 5602-5605.

Pollard, T. D., and M. S. Mooseker (1981) Direct measurement of actin polymerization rate constants by electron microscopy of actin filaments nucleated by isolated microvillus cores. J. Cell Biol. 88: 654-659.

Reichardt, L. F., and R. B. Kelly (1983) A molecular description of nerve terminal function. Annu. Rev. Biochem. 52: 871-926.

Robinson, P. J., and P. R. Dunkley (1983) Depolarisation-dependent protein phosphorylation in rat cortical synaptosome: Factors determining the magnitude of the response. J. Neurochem. 41: 909-918.

Siman, R., M. Baudry, and G. Lynch (1983) Purification from synaptosomal plasma membrane of calpain I, a thiol protease activated by micromolar calcium concentrations. J. Neurochem. 41: 950-956.

Sobue, K. S., K. Kanda, J. Adachi, and S. Kakiuchi (1983) Calmodulinbinding proteins that interact with actin filaments in a $\mathrm{Ca}^{2+}$-dependent flipflop manner: Survey in brain and secretory tissues. Proc. Natl. Acad. Sci. U. S. A. 80: $6868-6871$.

Spooner, B. S., and C. R. Halladay (1981) Distribution of tubulin and actin in neurites and growth cones of differentiating nerve cells. Cell Motil. 1:167178.

Suszkiw, J. B., and M. E. O'Leary (1983) Temporal characteristics of potassium-stimulated acetycholine release and inactivation of calcium influx in rat brain synaptosomes. J. Neurochem. 41: 868-873.

Swanston-Flatt, S. K., L. Carlsson, and E. Gylfe (1980) Actin filament formation in pancreatic $\beta$-cells during glucose stimulation of insulin secretion. FEBS Lett. 117: 299-302.

Tsui, H. -C. T., H. Ris, and W. L. Klein (1983) Ultrastructural networks in growth cones and neurites of cultured central nervous system neurons. Proc. Natl. Acad. Sci. U. S. A. 80: $5779-5783$.

Wallace, P. J., R. P. Wersto, C. H. Packman, and M. A. Lichtman (1984) Chemotactic peptide-induced changes in neutrophil actin conformation. $J$. Cell Biol. 99: 1060-1065.

Wang, L. L., and J. Bryan (1981) Isolation of calcium dependent platelet proteins that interact with actin. Cell 25: 637-649.

White, J. R., P.H. Nacchache, and R. I. Sha'afi (1983) Stimulation by chemotactic factor of actin association with the cytoskeleton in rabbit neutrophils. J. Biol. Chem. 258: 14041-14047.

Yamada, K. M., B. S. Spooner, and N. K. Wessells (1971) Ultrastructure and function of growth cones and axons of cultured nerve cells. J. Cell Biol. 49: 614-635. 